\title{
Nephrotoxicity and genotoxicity of silver nanoparticles in juvenile rats and possible mechanisms of action
}

\author{
Ye Liu ${ }^{1,2}$, Li Sun ${ }^{1}$, Guili Yang ${ }^{1}$, and Zhuo Yang ${ }^{2}$ \\ ${ }^{1}$ Tianjin Medical University General Hospital, Ministry of Education and Tianjin City, Tianjin Neurological Institute, Key \\ Laboratory of Post-Neuroinjury Repair and Regeneration in Central Nervous System, Tianjin, China \\ ${ }^{2}$ Nankai University College of Medicine, State Key Laboratory of Medicinal Chemical Biology, Key Laboratory of \\ Bioactive Materials for Ministry of Education, Tianjin, China
}

[Received in November 2019; Similarity Check in November 2019; Accepted in May 2020]

Because of their widespread use and potential adverse effects in young developing organism, this study focused on the nephrotoxicity and genotoxicity of chronic low-dose exposure to silver nanoparticles (AgNPs) in 32 14-day-old male Wistar rats, randomly divided into three groups receiving AgNP solution ( $3 \mathrm{mg} / \mathrm{kg}$ body weight) intraperitoneally for one, two, or three weeks and the untreated control group (eight animals per group). When the rats were eight weeks old, blood creatinine and urine microalbumin were tested, followed by haematoxylin and eosin (H\&E) staining. Proteinuria was found in the animals treated with AgNP for three weeks, and H\&E staining revealed pathological changes in the kidney sections of this group. DNA damage was detected with the alkaline comet assay in the groups treated for two and three weeks. All results indicate that chronic exposure, even at a low dose, may affect animal health. The main culprit might be increased and time-dependent reactive oxygen species (ROS) production. Highly reactive ROS could cause a major structural damage to proteins and DNA, change the expression of ion channel proteins, and trigger inflammation. The findings of our in vivo experiment raise concern about nephrotoxic and genotoxic effects of silver nanoparticles in young organisms and call for further investigation of nanoparticle properties that can be modified to minimise the risks.

KEY WORDS: alkaline comet assay; inflammation; oxidative stress; trpc6 cation channel

Nanoparticles are materials whose at least one dimension is within the $1-100 \mathrm{~nm}$ range. As their size determines their physicochemical properties and can give them an edge over or complement standard chemicals (1), nanomaterials are being rapidly developed for a wide range of uses in all industrial and public sectors. One such material are silver nanoparticles (AgNPs), whose broad-spectrum antimicrobial properties find use in medicinal and everyday products such as diapers, baby bottles, and baby wipes $(2,3)$.

However, some animal studies report that silver ions can accumulate in body organs and that AgNPs can have toxic effects on the liver and kidney $(4,5)$. Considering that the kidneys in a young, developing organism are much more sensitive to exogenous compounds than those in a mature system, it is important to assess the potential of AgNPs to cause developmental nephrotoxicity and genotoxicity. This is the primary aim of this study in juvenile Wistar rats, as this issue has received little attention so far.

The secondary aim was to see whether the main cause of these effects is oxidative stress and its downstream pathways. Having a larger surface area, nanoparticles may induce higher free radical and reactive oxygen species (ROS) production than their non-nanoform chemical

Corresponding author: Professor Zhuo Yang, Nankai University College of Medicine, Tianjin 300071, China, E-mail: zhuoyang@nankai.edu.cn counterparts $(6,7)$. Earlier research suggests that the major enzymatic source of ROS in AgNP-induced cytotoxicity is nicotinamide adenine dinucleotide phosphate (NADPH) oxidase, also known as NOX (8). Its isoform NOX4 is highly expressed in the kidney and has an important role in kidney diseases $(9,10)$. Changes in NOX4 levels may reflect on ROS production, and excessive production can lead to oxidative stress and inflammation that can eventually lead to the development of chronic kidney disease (11).

ROS effects on cellular processes are mediated by multiple downstream pathways, and the $\mathrm{Ca}^{2+}$ signalling pathway is perhaps the most important, because $\mathrm{Ca}^{2+}$ cell homeostasis is redox-sensitive (12-15), and the $\mathrm{Ca}^{2+}$ permeable transient receptor potential cation channel 6 (TRPC6) is widely expressed in kidney cells, including podocytes (16), glomerular mesangial cells (17), and endothelial cells (18). Animal studies have showed that podocyte-specific transgenic TRPC6 overexpression can lead to albuminuria and histological findings similar to human focal segmental glomerulosclerosis (FSGS) (19). Wang et al. (20) have already shown that TRPC6 is redoxsensitive and suggested that ROS could regulate $\mathrm{Ca}^{2+}$ signalling by altering TRPC6 protein expression or TRPC6 channel activity in kidney cells.

In addition, nanoparticles may elicit genotoxic effects, as ROS can react with the DNA (21), and evidence of in

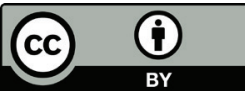


vitro and in vivo genotoxic effects of AgNPs is growing $(22,23)$.

\section{MATERIALS AND METHODS}

\section{Materials}

The silver nanoparticles (Figure 1) used in this research were obtained from the University of Hertfordshire, England, UK. They were suspended in deionised water at a concentration of $1 \mathrm{mg} / \mathrm{mL}$ and dispersed with ultrasonic vibration for 20 min before everyday injection. The mean hydrodynamic particle size in suspension was $98.3 \mathrm{~nm}$ (range 30.3-178.1 nm due to aggregation) as measured with dynamic light scattering (DLS) using a Zeta-PALS+BI-90 Plus (Brookhaven Instruments Corporation, Hotsville, NY, USA) at a wave length of $659 \mathrm{~nm}$ and the scattering angle of $90^{\circ}$. Surface area, measured with the Brunauer Emmett and Teller (24) method was $114 \mathrm{~m}^{2} / \mathrm{g}$. The Zeta potential of -36.58 was measured in the suspension with a combination of laser Doppler velocimetry and phase analysis light scattering (PALS) using Zeta-PALS+BI-90 Plus.

As for other materials we used the reactive oxygen species assay kit (Nanjing Jiancheng, Nanjing, China), rabbit polyclonal anti-TRPC6 antibodies, rabbit polyclonal anti-NADPH oxidase 4 (primary antibody) (Abcam, Cambridge, MA, USA), Alexa 488-conjugated goat antirabbit IgG antibodies (secondary antibody, working dilution 1:1000) (Invitrogen, San Diego, CA, USA), rabbit polyclonal anti- $\beta$-actin IgG (primary antibody, working dilution 1:1000) (Santa Cruz Biotechnology, Inc., Santa Cruz, CA, USA), chemiluminescent HRP substrate (Immobilon Western, Millipore Corporation, Billerica, MA, USA), haematoxylin and eosin (H\&E) staining kit (Solarbio, Beijing, China), creatinine (Cr) assay kit (Nanjing

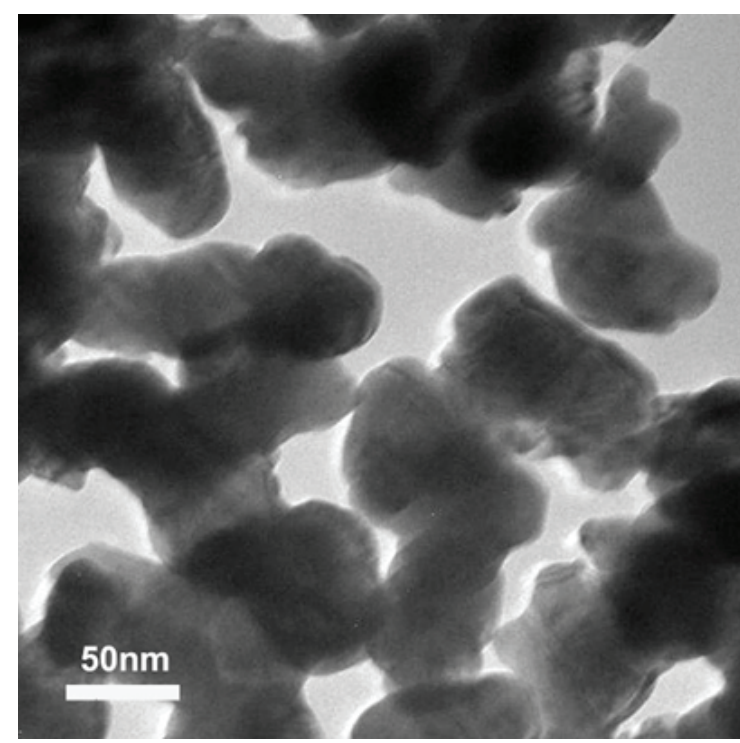

Figure 1 Transition electron microscopy of silver nanoparticles in suspension
Jiancheng), microalbumin assay kit (Nanjing Jiancheng), total protein assay kit (Nanjing Jiancheng), enzyme-linked immunosorbent assay (ELISA) kit for nicotinamide adenine dinucleotide phosphate oxidase 4 (NOX4) (Shanghai Enzyme-linked Biotechnology Co., Ltd. Shanghai, China), rat IL-6 ELISA kit and rat TNF- $\alpha$ ELISA kit (NeoBioscience, Guangdong, China), rat IL-1 $\beta$ ELISA kit (BioGems, New Jersey, NJ, USA), GelRed ${ }^{\mathrm{TM}}$ nucleic acid gel stain (Biotium, San Francisco, CA, USA), and radioimmunoprecipitation assay (RIPA) lysis buffer (Beyotime, Shanghai, China).

\section{Animals and AgNP treatment}

Figure 2 shows the experimental design for this study, in which we used 32 Wistar male rats. The pups were housed with the dam and their litter until weaning on postnatal day 21 , after which they were randomly assigned to either the control or one of the three treatment groups, eight to each, and moved to respective cages. All three treatment groups received intraperitoneal injection of AgNP solution with $3 \mathrm{mg}$ of AgNP per $\mathrm{kg}$ of body weight (bw) every day. This dose was based on our previous findings of its effects (lower doses showed none) (7) and preliminary analysis. The first group was treated with AgNPs for one week (1-wk-AgNP), the second for two weeks (2-wk-AgNP), and the third for three weeks (3-wk-AgNP). The control group received sterile saline alone.

We observed specific pathogen-free conditions throughout the experiment. The environmental conditions were kept at $22 \pm 1{ }^{\circ} \mathrm{C}$ and $45-55 \%$ relative humidity, with a 12:12 h light/dark cycle. Clean water and conventional diet were provided ad libitum.

When the rats reached adulthood at eight weeks, they were killed under isoflurane anaesthesia and their blood and urine samples collected and kidneys removed.

All the protocols were approved by the Committee for Animal Care of Tianjin Medical University. All animal experiments complied with the EU Directive 2010/63/EU (25). The experiment was designed to minimise the number of animals used and their suffering.

\section{Creatinine and urinary microalbumin detection}

Depending on the treatment group, the animals were given time to recover from AgNP exposure until they reached adulthood at 8 weeks. Overnight urine samples were collected in metabolic cages and blood samples drawn from the tail vein with a syringe. Urinary microalbumin was detected with the microalbumin assay kit. Serum was harvested after blood centrifugation at $1902 \times \mathrm{g}$ for $10 \mathrm{~min}$ and creatinine measured with the creatinine assay kit. All procedures were performed following the kit instructions.

\section{Alkaline comet assay}

The micronucleus and the single-cell gel electrophoresis (comet) are the most common tests used in vitro or in vivo to investigate genotoxicity of nanoparticles (26-28). We 


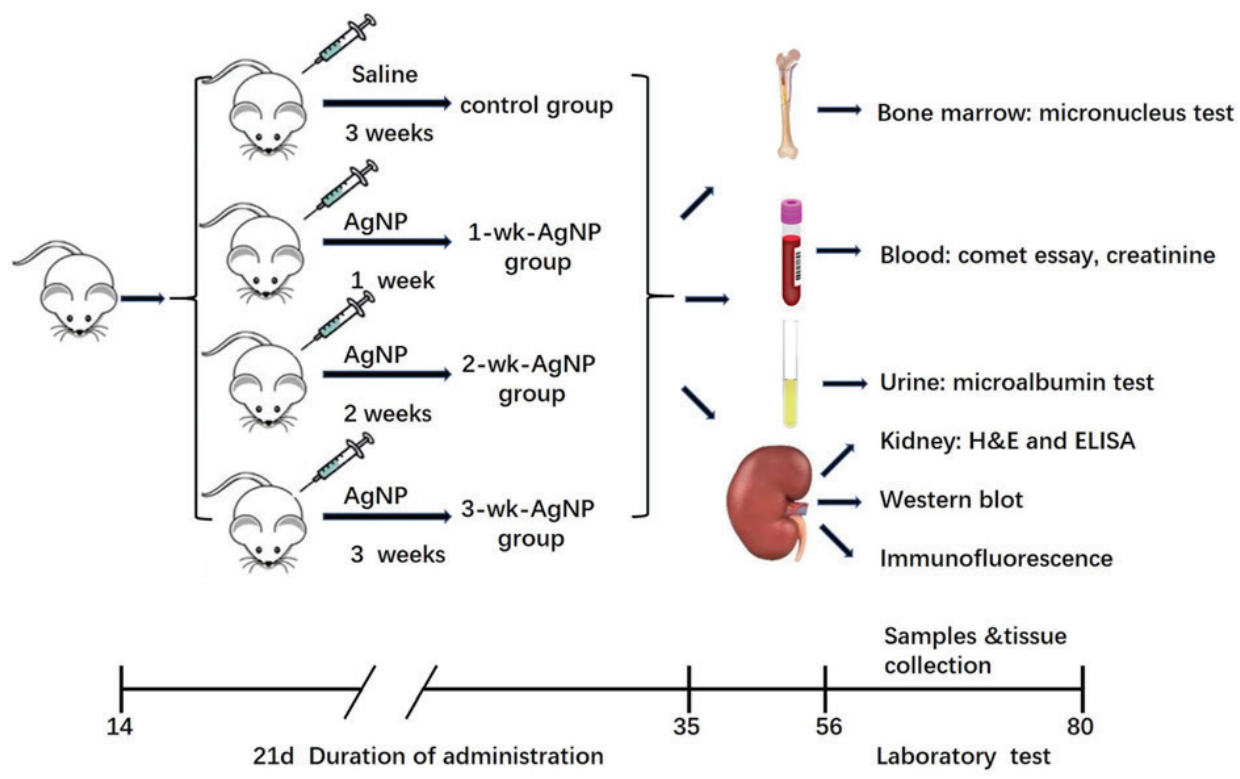

Figure 2 Experimental design of AgNP administration, sampling, and tissue collection; AgNP - silver nanoparticles; H\&E - haematoxylin and eosin; ELISA - enzyme-linked immunosorbent assay

performed the comet assay as described by Tice et al. (29) and Machado et al. (30). Cell viability was above $90 \%$, according to the trypan blue dye exclusion method. Samples of peripheral blood were immediately mixed with $0.5 \%$ of low melting point agarose dissolved in phosphate-buffered saline (PBS) and spread on microscope slides precoated with $1.5 \%(\mathrm{w} / \mathrm{v})$ of normal melting point agarose. After solidification of the gel (within about an hour), the coverslips were gently removed and the slides immersed in cold $\left(4^{\circ} \mathrm{C}\right)$ lysis solution $(2.5 \mathrm{~mol} / \mathrm{L} \mathrm{NaCl}, 100 \mathrm{mmol} / \mathrm{L}$ EDTA, $1 \%(\mathrm{v} / \mathrm{v})$ triton $\mathrm{X}-100$, and $10 \mathrm{mmol} / \mathrm{L}$ Tris at $\mathrm{pH} 10$ ) for $24 \mathrm{~h}$. After that, the slides were placed in a horizontal electrophoresis unit containing freshly prepared electrophoresis buffer $(300 \mathrm{mmol} / \mathrm{L} \mathrm{NaOH}$ and $1 \mathrm{mmol} / \mathrm{L}$ EDTA) for $20 \mathrm{~min}$ at an electric field strength of $0.78 \mathrm{~V} / \mathrm{cm}$ $(25 \mathrm{~V}$ and $300 \mathrm{~mA})$. When electrophoresis was over, the slides were immersed in a neutralisation buffer $(0.4 \mathrm{~mol} / \mathrm{L}$ Tris- $\mathrm{HCl}, \mathrm{pH} 7.5$ ) for $5 \mathrm{~min}$ and stained with GelRed ${ }^{\mathrm{TM}}$ $(1: 10,000)$. All slides were randomly coded for five animals per group. For each slide (two per rat) we scored 50 cells using the Comet Assay IV ${ }^{\circledR}$ software (Perceptive Instruments Ltd., Suffolk, UK), and determined tail intensity (\% DNA in tail) as the genotoxicity parameter.

\section{Bone marrow cell micronucleus test}

The frequency of micronuclei is a characteristic parameter indicative of chromosomal loss and breakage (20). Bone marrow cells of five animals per group were harvested following the method described by Salamone et al. (31) and the micronucleus test performed as described by Schmid (32). After being homogenised and centrifuged at $400 \times g$ for $10 \mathrm{~min}$, the cells were resuspended and layered on a microscopic slide. The slides were randomly coded, fixed in absolute methanol for $10 \mathrm{~min}$, and stained with Giemsa. Two slides were prepared per animal. Two thousand polychromatic erythrocytes (PCE) were scored per animal (10,000 per group) for the occurrence of micronuclei. Normochromatic erythrocytes (NCE) were counted in parallel to calculate the PCE to NCE ratio.

\section{Kidney ROS, glutathione, and superoxide dismutase assays}

After blood and urine sample collection, the rats were killed and their kidneys removed and prepared for singlecell suspensions. Half of the suspension volume was used to determine the levels of ROS, glutathione (GSH), and superoxide dismutase (SOD) following kit instructions. The other half was used to determine protein concentrations.

\section{Inflammatory cytokine determination}

Inflammatory cytokines (IL-1 $\beta$, IL-6, and TNF- $\alpha$ ) were determined in kidney tissue homogenates with the ELISA kits following kit instructions.

\section{Western blotting}

Renal cortex was isolated, minced into fragments, and lysed in a lysis buffer containing a protease inhibitor cocktail (1:1000 dilutions). After preparation of protein extracts, western blotting was conducted as described elsewhere (33). For the analysis, we quantified the intensity of hybridisation signals. Image J program (https://imagej. nih.gov/ij/) was used to evaluate differences between the samples of interest and respective $\beta$-actin.

\section{Immunofluorescence staining}

Kidney samples were embedded in the optimum cutting temperature (OCT) formulation (Tissue-Tek, Torrance, CA, USA) after being fixed in $4 \%$ paraformaldehyde for $24 \mathrm{~h}$ 
and dehydrated in $30 \%$ sucrose solution at $4{ }^{\circ} \mathrm{C}$ overnight. Seven micron thick slices were cut with a freezing microtome (Leica CM 1850, Leica Microsystems Nussloch, Wetzlar, Germany) and washed in PBS three times for $5 \mathrm{~min}$ and then incubated in a blocking buffer with $10 \%$ goat serum for $1 \mathrm{~h}$. After that, the slices were incubated in primary antibody (anti-TRPC6, 1:1000) at $4{ }^{\circ} \mathrm{C}$ overnight. Sections were protected from light, washed in PBS three times for $10 \mathrm{~min}$ to get rid of non-specific binding, and incubated in Alexa 488-conjugated anti-rabbit IgG. When all the steps were finished, fluorescent images were inspected with a Leica TCS SP5 laser-scanning confocal microscope (40x magnification). Image-Pro Plus software (Version VI; Media Cybernetics, Silver Springs, MD, USA) was used to quantify intensity in the renal slices. For TRPC6 expression analysis, three sections were selected randomly from one kidney sample, and there were eight samples for each group.

\section{Histology}

Rat kidneys for histological analysis were removed carefully and fixed in a $10 \%$ formalin solution containing neutral PBS. After dehydration with graded ethanol and vitrification with dimethylbenzene, the organs were embedded in paraffin, cut into slices, H\&E-stained following the kit instructions, and examined under a light microscope (40x magnification, Nikon, Tokyo, Japan).

\section{Statistical analysis}

Means \pm standard errors (SEM) of all data were analysed using one-way analysis of variance (ANOVA) followed by a Newman-Keuls post hoc test. Animal body weights were analysed with two-way ANOVA with groups as betweensubject factor and time as repeated measure. All analyses were run with statistical software SPSS v. 17.0. (IBM, Armonk, NY, USA). $P<0.05$ was considered significant.

\section{RESULTS}

\section{Physical findings}

No mortality related to AgNP administration was observed during this study. There were no significant differences in body weight between the control and AgNPtreated groups (Figure 3A).

\section{Urinary microalbumin and serum creatinine findings}

Urinalysis results are shown in Figure 3B. Urinary microalbumin was significantly higher in the 3-wk-AgNP group than controls $[\mathrm{F}(3,28)=3.83, P<0.05]$, but it did not differ significantly from the other two treatment groups. Serum creatinine showed no statistical differences between any of the four groups, although it was slightly higher in the 2- and 3-wk-AgNP group than controls $[\mathrm{F}(3,28)=1.67$, $P>0.05]$ (Figure 3C).

\section{Alkaline comet assay findings}

Significantly higher tail intensity in the 2- and 3-wkAgNP groups than controls $[\mathrm{F}(3,28)=3.07, P<0.05]$ suggests that the DNA damage depended on the length of nanoparticle exposure.

\section{Micronucleus test findings}

Figure 3E shows the frequency of micronucleated PCEs in bone marrow, while Figure $3 \mathrm{~F}$ shows the PCE to NCE ratio. The 3-wk-AgNP group had a significantly higher micronucleus frequency than controls $[\mathrm{F}(3,28)=3.18$, $P<0.05]$, but there was no statistical difference in the PCE to NCE ratio between any of the groups $[\mathrm{F}(3,28)=2.32$, $P>0.05]$.

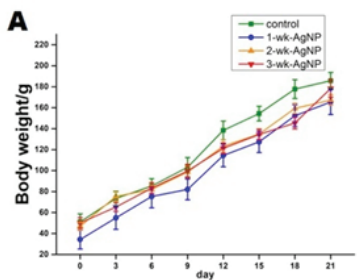

D

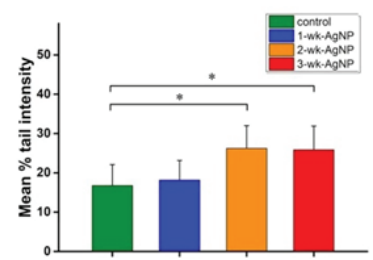

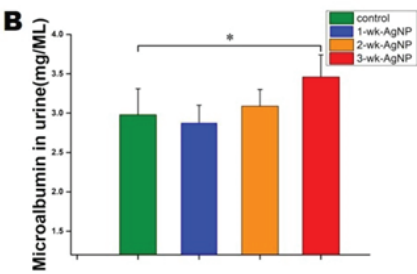

E

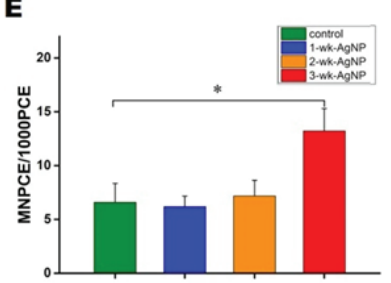

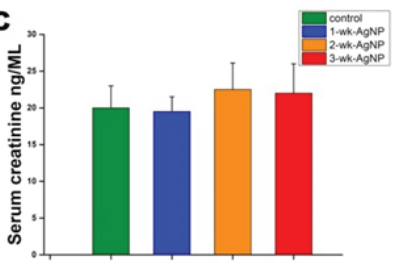

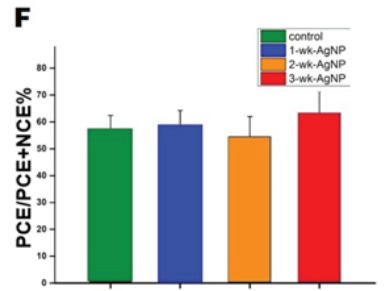

Figure 3 Mean ( \pm SEM) body weight (A), urinary microalbumin (B), serum creatinine (C), tail intensity (comet assay) (D), the frequency of micronucleated PCEs in bone marrow (E), and the PCE to NCE ratio (F) in control and juvenile rats treated with AgNPs for one, two, or three weeks ( $\mathrm{n}=8$ per group); ${ }^{*}<<0.05 ; \mathrm{AgNP}$ - silver nanoparticles; $\mathrm{NCE}$ - normochromatic erythrocytes; $\mathrm{PCE}$ - polychromatic erythrocytes; SEM - standard error of the mean 
A

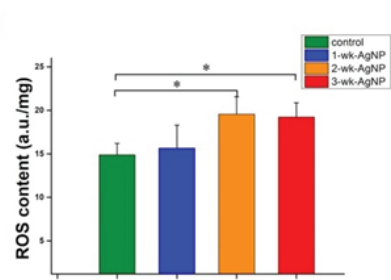

D

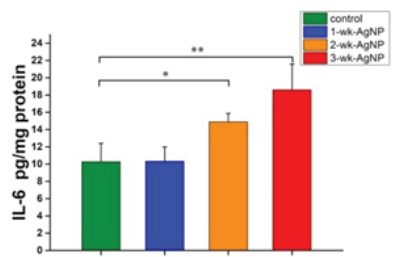

B

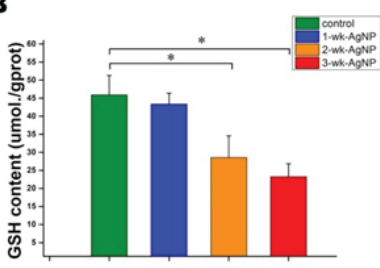

$\mathbf{E}$

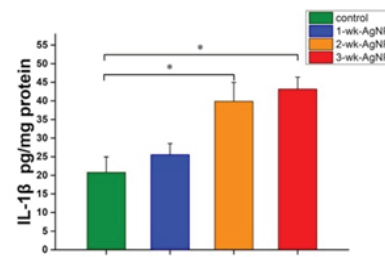

C

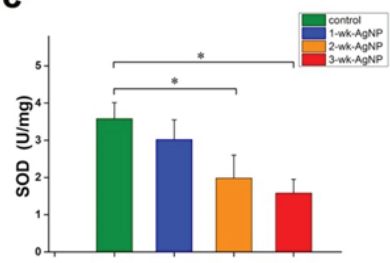

$\mathbf{F}$

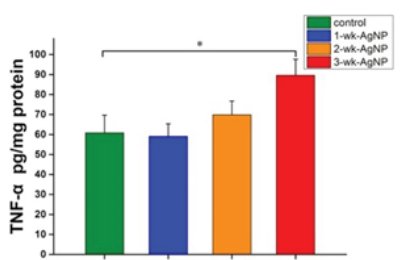

Figure 4 Mean $( \pm$ SEM) ROS GSH, SOD IL-6, IL-1 $\beta$, and TNF- $\alpha$ in kidney cells and tissue of control and juvenile rats treated with AgNPs for one, two, or three weeks ( $\mathrm{n}=8$ per group); ${ }^{*} P<0.05$; GSH - glutathione; IL - interleukin; ROS - reactive oxygen species; SEM - standard error of the mean; SOD - superoxide dismutase; TNF - tumour necrosis factor

A

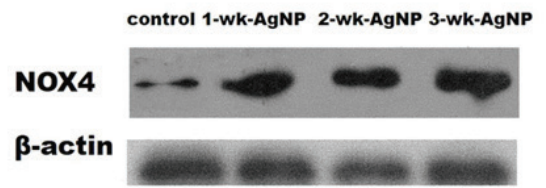

B

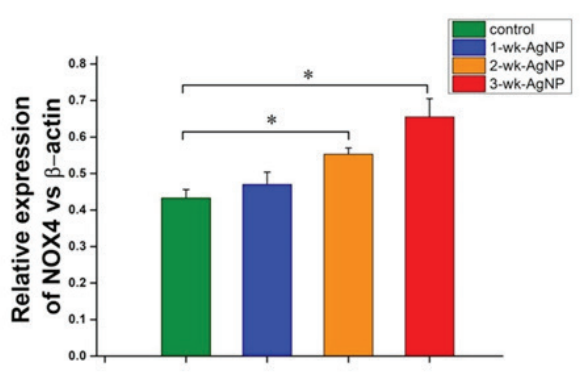

C control 1-Wk-AgNP 2-Wk-AgNP 3-Wk-AgNP TRPC6 $\beta$-actin

D

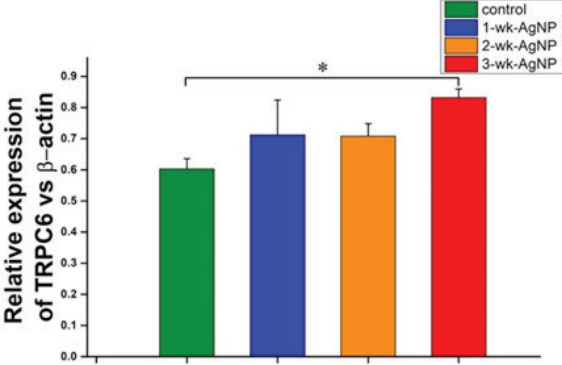

Figure 5 Mean ( \pm SEM) NOX4 and TRPC6 in rat renal cortex (normalised to $\beta$-actin expression) of control and juvenile rats treated with AgNPs for one, two, or three weeks ( $\mathrm{n}=8$ per group); ${ }^{*} P<0.05$; NOX - NADPH oxidase 4; SEM - standard error of the mean; TRPC6 - transient receptor potential cation channel subfamily C member 6

\section{Kidney ROS, GSH, and SOD findings}

The 2- and 3-wk-AgNP groups had significantly higher $\operatorname{ROS}[\mathrm{F}(3,28)=3.31, P<0.05]$ (Figure 4A) and significantly lower GSH and SOD levels in the kidney tissue than control $[\mathrm{F}(3,28)=3.36, P<0.05]$ (Figure 4B and 4C).

\section{Inflammatory cytokine findings}

Figure 4D-F shows inflammatory cytokine levels in the four groups. As expected, IL-6 and IL-1 $\beta$ were significantly higher in the 2- and 3-wk-AgNP groups than control $[\mathrm{F}(3,28)=3.72$ and 3.28 , respectively, $P<0.05]$ (Figure 4D and $4 \mathrm{E})$, while the level of TNF- $\alpha$ was significantly higher only in the 3 -wk-AgNP group $[\mathrm{F}(3,28)=3.16, P<0.05]$ (Figure 4F). We also observed a coincidence in trends between inflammatory cytokines and ROS levels, which suggests a link between inflammation and oxidative stress.

\section{Western blot findings}

The 2- and 3-wk-AgNP groups showed significantly higher expression of NOX4 than controls $[\mathrm{F}(3,28)=3.09$, $P<0.05$ ] (Figure 5B), which suggests that higher ROS production was at least partly owed to the mobilisation of NOX4. At the same time, TRPC6 expression was significantly higher only in the 3 -wk-AgNP group $[\mathrm{F}(3,28)=2.98, P<0.05]$ (Figure 5D).

\section{Immunofluorescence staining findings}

Figure 6A shows TRPC6 in the glomeruli and tubules of the kidney cortex and its fluorescent intensity (Figure $6 \mathrm{~B})$, which was significantly higher only in the 3-wk-AgNP group compared to control $[\mathrm{F}(3,28)=3.23, P<0.05]$. 


\section{$H \&$ E staining findings}

H\&E staining revealed pathological changes of several glomeruli in the 3-wk-AgNP group, which included glomerular cell proliferation, thickened basement membrane, fusion of glomerulus and renal capsule, and proliferation in the mesangial cell and mesangial matrix. The interstitial areas were infiltrated with inflammatory cells. Renal tubules did not show pathological changes (Figure 7).

\section{DISCUSSION}

Our study suggests that chronic exposure to silver nanoparticles can cause DNA damage, inflammation, and TRPC6 overexpression due to oxidative stress, which, in turn, may lead to nephrotoxicity and genotoxicity (Figure 8). Our findings also suggest that these effects are related to exposure duration. Unlike the in vivo study by Sarhan et al. (34), in which an acute AgNP dose of 2,000 mg/ $\mathrm{kg}$ body weight induced significant structural and functional liver and kidney damage, we observed only mild functional damage and pathological changes in the kidneys of our juvenile rats. However, even our small dose ( $3 \mathrm{mg} / \mathrm{kg}$ body weight), which reflects real-life daily exposure to AgNPs through products such as diapers, baby bottles, or nanosilver baby wipes, suggests that frequent exposure may affect human health if it exceeds a toxicological threshold.

The in vivo comet assay and micronucleus test only confirmed time-dependent (genotoxic and chromosomal damage) effects, which were the most prominent after three weeks of exposure.

A

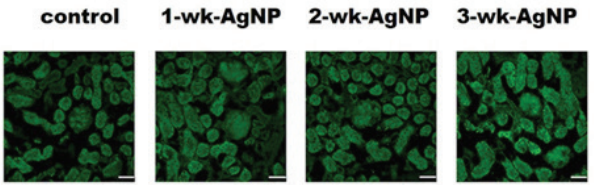

B

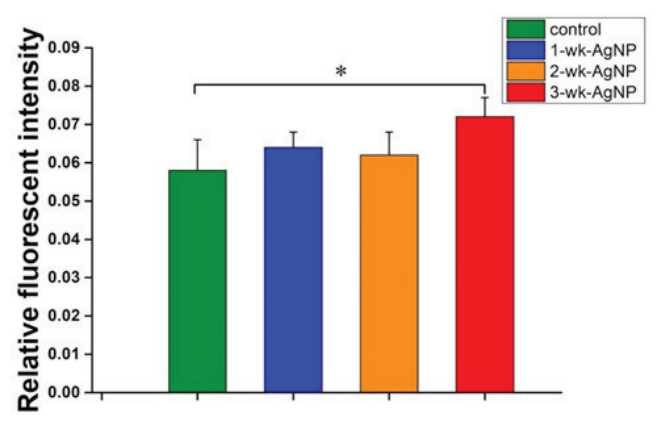

Figure 6 TRPC6 immunofluorescence staining of the renal cortex (50 $\mu \mathrm{m}$ scale bar) (A) and mean $( \pm$ SEM) fluorescent intensity (B) in the glomeruli of control and juvenile rats treated with AgNPs for one, two, or three weeks ( $n=8$ per group); ${ }^{*} P<0.05$; SEM standard error of the mean; TRPC6 - transient receptor potential cation channel subfamily $\mathrm{C}$ member 6
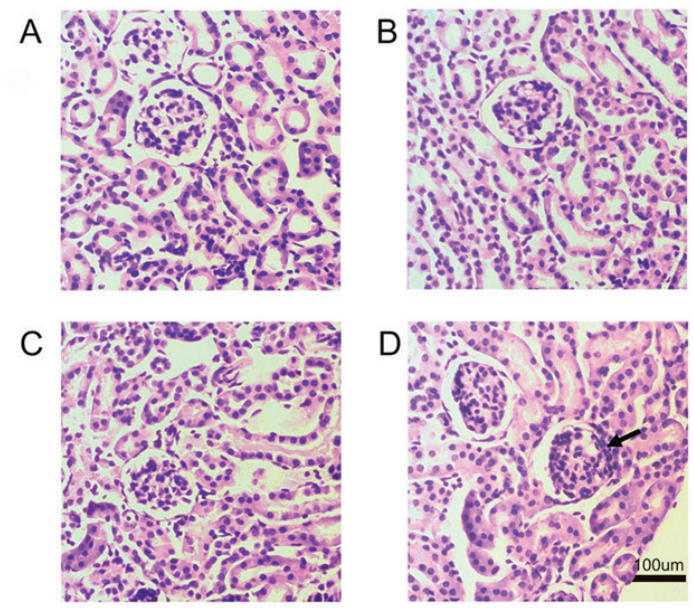

Figure 7 Histological findings in the kidney of juvenile rats: (A) control group, (B) 1-wk-AgNP group (C) 2-wk-AgNP group; (D) 3 -wk-AgNP group (100 $\mu \mathrm{m}$ scale bar; arrows indicate typically affected areas)

What could be the likely mechanisms of nephrotoxicity and genotoxicity of AgNPs? Our previous study showed that AgNPs can cause brain damage owing to excessive generation of ROS (7). With significantly higher ROS levels after two and three weeks of exposure, this study seems to confirm oxidative stress as one likely mechanism. Furthermore, we observed a coincidence between DNA damage and increased ROS, accompanied by a significant decline in antioxidant (SOD) and GSH levels. This may have caused an oxidative imbalance that has given rise to oxidative stress.

Findings that silver nanoparticles induce oxidative stress by generating excess ROS have already been reported for the hepatoma cells in vitro (35). Highly reactive ROS seems to be generated by accumulated AgNPs in mitochondria and lysosomes, which then leads to major structural damage to proteins and DNA $(36,37)$. According to another study (10), the NOX family, NOX4 in particular, is the major source of renal ROS. Our study evidences a consistency between up-regulated NOX4 and ROS production, which points to NOX4 as the main source of AgNP-induced toxicity.

One of the oxidative stress pathways is inflammation. It has been reported in the pathogenesis of chronic kidney disease (11), and excessive ROS has been reported to activate mediator signalling molecules which trigger the production of inflammatory cytokines such as IL- $1 \beta$ or TNF- $\alpha(38,39)$. The upregulated expression of TNF- $\alpha$, IL-1 $\beta$, and IL-6 after two- and three-week exposure to AgNPs in our study confirms the link between proinflammatory cytokines and ROS and suggests that excessive ROS production might play a part in AgNPinduced nephrotoxicity.

In addition, a number of studies (12-15) have confirmed that $\mathrm{Ca}^{2+}$ homeostatic proteins are redox-sensitive, which makes the $\mathrm{Ca}^{2+}$ signalling pathway an important target of 


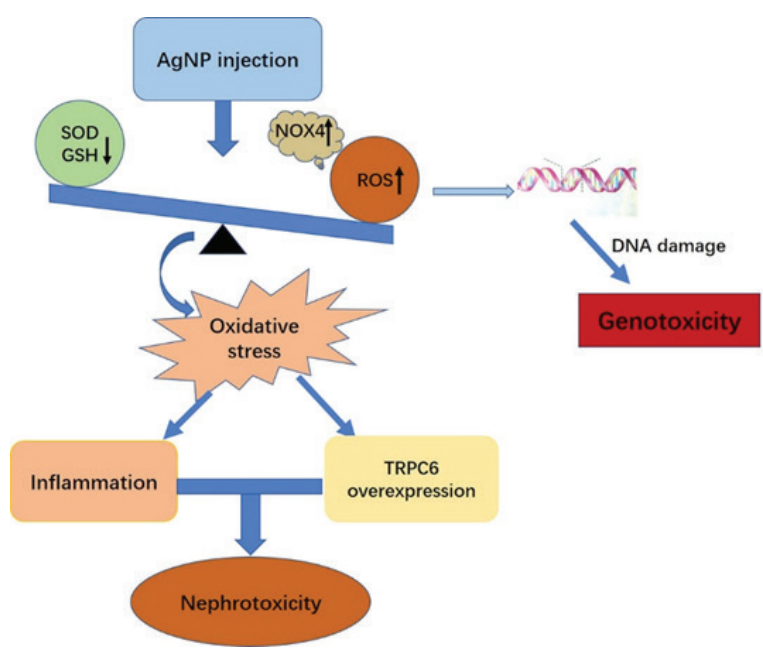

Figure 8 Diagram of the main likely mechanisms of AgNP nephrotoxicity based on oxidative stress; AgNP - silver nanoparticles; H\&E - haematoxylin and eosin; ELISA - enzymelinked immunosorbent assay; GSH - glutathione; ROS - reactive oxygen species; SOD - superoxide dismutase; TRPC6 - transient receptor potential cation channel subfamily $\mathrm{C}$ member 6

ROS. One such widely expressed $\mathrm{Ca}^{2+}$ channel in the kidney is the slit diaphragm-associated channel TRPC6 involved in regulating glomerular filtration, whose failure is closely related to proteinuria (40). Apparently, overexpression of TRPC6 causes retraction and loss of podocyte foot processes, which are responsible for filtration (41). Our study has shown exactly that, an overexpression of TRPC6 after a three-week exposure to AgNP, which was consistent with the urinary microalbumin findings.

The other course of AgNP action is DNA damage in young rats observed in our study, which increases the risk of carcinogenesis. However, our study does not suggest a specific mechanism in that respect and calls for further investigation.

Even so, it provides clear evidence that long-term, lowdose (chronic) exposure to silver nanoparticles can cause mild nephrotoxicity and genotoxicity in juvenile rats. The interpretation of our results is limited by the number of animals and dosage range. We still need to find out whether the effects of silver nanoparticles are dose-dependent and if they target organs. In addition, a new animal study is needed to find out if there is a safe dosage (threshold) for AgNPs. New research should also try to answer how ROS production is related to nanoparticle size, shape, surface area, and chemistry $(6,42-46)$. This information may greatly help to modify physical and chemical properties of silver nanoparticles to minimise the risks associated with their various applications.

\section{Acknowledgments}

We wish to thank Dr Guogang Ren of the University of Hertfordshire, England, UK for donating the silver nanoparticles used in this research and providing detailed information given in the methods section. This research was supported by the National Natural Science Foundation of China (grant Nos. 81601039, 81571201, and 81501069).

\section{Conflicts of interest}

None to declare.

\section{REFERENCES}

1. Maynard AD, Aitken RJ. "Safe handling of nanotechnology" ten years on. Nat Nanotechnol 2016;11:998-1000. doi: 10.1038/nnano.2016.270

2. West JL, Halas NJ. Engineered nanomaterials for biophotonics applications: improving sensing, imaging, and therapeutics. Annu Rev Biomed Eng 2003;5:285-92. doi: 10.1146/ annurev.bioeng.5.011303.120723

3. Chen X, Schluesener HJ. Nanosilver: a nanoproduct in medical application. Toxicol Lett 2008;176:1-12. doi: 10.1016/j.toxlet.2007.10.004

4. Park EJ, Bae E, Yi J, Kim Y, Choi K, Lee SH, Yoon J, Lee BC, Park K. Repeated-dose toxicity and inflammatory responses in mice by oral administration of silver nanoparticles. Environ Toxicol Pharmacol 2010;30:162-8. doi: 10.1016/j.etap.2010.05.004

5. Kouame K, Peter AI, Akang EN, Adana M, Moodley R, Naidu EC, Azu OO. Effect of long-term administration of Cinnamomum cassia silver nanoparticles on organs (kidneys and liver) of Sprague-Dawley rats. Turk J Biol 2018;42:498505. doi: 10.3906/biy-1805-103

6. Nel A, Xia T, Madler L, Li N. Toxic potential of materials at the nanolevel. Science 2006;311:622-7. doi: 10.1126/ science. 1114397

7. Liu Y, Guan W, Ren G, Yang Z. The possible mechanism of silver nanoparticle impact on hippocampal synaptic plasticity and spatial cognition in rats. Toxicol Lett 2012;209:227-31. doi: 10.1016/j.toxlet.2012.01.001

8. Sun X, Yang Y, Shi J, Wang C, Yu Z, Zhang H. NOX4- and Nrf2-mediated oxidative stress induced by silver nanoparticles in vascular endothelial cells. J Appl Toxicol 2017;37:142837. doi: $10.1002 /$ jat.3511

9. Schreck C, O'Connor PM. NAD $(\mathrm{P}) \mathrm{H}$ oxidase and renal epithelial ion transport. Am J Physiol Regul Integr Comp Physiol 2011;300:R1023-9. doi: 10.1152/ajpregu.00618.2010

10. Sedeek M, Nasrallah R, Touyz RM, Hébert RL. NADPH oxidases, reactive oxygen species, and the kidney: friend and foe. J Am Soc Nephrol 2013;24:1512-8. doi: 10.1681/ ASN.2012111112

11. Tucker PS, Scanlan AT, Dalbo VJ. Chronic kidney disease influences multiple systems: describing the relationship between oxidative stress, inflammation, kidney damage, and concomitant disease. Oxid Med Cell Longev 2015;2015:806358. doi: 10.1155/2015/806358

12. Favero TG, Zable AC, Abramson JJ. Hydrogen peroxide stimulates the $\mathrm{Ca}^{2+}$ release channel from skeletal muscle sarcoplasmic reticulum. J Biol Chem 1995;270:25557-63. doi: $10.1074 / j b c .270 .43 .25557$

13. Hidalgo C, Donoso P. Crosstalk between calcium and redox signaling: from molecular mechanisms to health implications. Antioxid Redox Signal 2008;10:1275-312. doi: 10.1089/ ars.2007.1886 
14. Tabet F, Savoia C, Schiffrin EL, Touyz RM. Differential calcium regulation by hydrogen peroxide and superoxide in vascular smooth muscle cells from spontaneously hypertensive rats. J Cardiovasc Pharmacol 2004;44:200-8. doi: 10.1097/00005344-200408000-00009

15. Trebak M, Ginnan R, Singer HA, Jourd'heuil D. Interplay between calcium and reactive oxygen/nitrogen species: an essential paradigm for vascular smooth muscle signaling. Antioxid Redox Signal 2010;12:657-74. doi: 10.1089/ ars. 2009.2842

16. Goel M, Sinkins WG, Zuo CD, Estacion M, Schilling WP. Identification and localization of TRPC channels in the rat kidney. Am J Physiol Renal Physiol 2006;290:F1241-52. doi: 10.1152/ajprenal.00376.2005

17. Sours S, Du J, Chu S, Ding M, Zhou XJ, Ma R. Expression of canonical transient receptor potential (TRPC) proteins in human glomerular mesangial cells. Am J Physiol Renal Physiol 2006;290:F1507-15. doi: 10.1152/ ajprenal.00268.2005

18. Reiser J, Polu KR, Moller CC, Kenlan P, Altintas MM, Wei C, Faul C, Herbert S, Villegas I, Avila-Casado C, McGee M, Sugimoto H, Brown D, Kalluri R, Mundel P, Smith PL, Clapham DE, Pollak MR. TRPC6 is a glomerular slit diaphragm-associated channel required for normal renal function. Nat Genet 2005;37:739-44. doi: 10.1038/ng1592

19. Krall P, Canales CP, Kairath P, Carmona-Mora P, Molina J, Carpio JD, Ruiz P, Mezzano SA, Li J, Wei C, Reiser J, Young JI, Walz K. Podocyte-specific overexpression of wild type or mutant TRPC6 in mice is sufficient to cause glomerular disease. PloS One 2010;5:e12859. doi: 10.1371/journal. pone. 0012859

20. Wang Z, Wei X, Zhang Y, Ma X, Li B, Zhang S, Yi F. NADPH oxidase-derived ROS contributes to upregulation of TRPC6 expression in puromycin aminonucleoside-induced podocyte injury. Cell Physiol Biochem 2009;24:619-26. doi: 10.1159/000257517

21. Donner M, Tran L, Muller J, Vrijhof H. Genotoxicity of engineered nanomaterials. Nanotoxicology 2010;4:345-6. doi: 10.3109/17435390.2010.482750

22. Kim YJ, Rahman MM, Lee SM, Kim JM, Park K, Kang JH, Seo YR. Assessment of in vivo genotoxicity of citrated-coated silver nanoparticles via transcriptomic analysis of rabbit liver tissue. Int J Nanomedicine 2019;14:393-405. doi: 10.2147/ IJN.S174515

23. Souza TA, Franchi LP, Rosa LR, da Veiga MA, Takahashi CS. Cytotoxicity and genotoxicity of silver nanoparticles of different sizes in CHO-K1 and CHO-XRS5 cell lines. Mutat Res Genet Toxicol Environ Mutagen 2016;795:70-83. doi: 10.1016/j.mrgentox.2015.11.002

24. Legras A, Kondor A, Heitzmann MT, Truss RW. Inverse gas chromatography for natural fibre characterisation: Identification of the critical parameters to determine the Brunauer-Emmett-Teller specific surface area. J Chromatogr A 2015;1425:273-9. doi: 10.1016/j.chroma.2015.11.033

25. Directive 2010/63/EU of the European Parliament and of the Council of 22 September 2010 on the protection of animals used for scientific purposes [displayed 21 May 2020] Available at: https://eur-lex.europa.eu/legal-content/EN/ TXT/HTML/?uri=CELEX:32010L0063\& from=EN

26. Singh N, Manshian B, Jenkins GJ, Griffiths SM, Williams PM, Maffeis TG, Wright CJ, Doak SH. NanoGenotoxicology: the DNA damaging potential of engineered nanomaterials.
Biomaterials 2009;30:3891-914. doi: 10.1016/j. biomaterials.2009.04.009

27. Landsiedel R, Kapp MD, Schulz M, Wiench K, Oesch F. Genotoxicity investigations on nanomaterials: methods, preparation and characterization of test material, potential artifacts and limitations - many questions, some answers. Mutat Res 2009;681:241-58. doi: 10.1016/j. mrrev.2008.10.002

28. Arora S, Rajwade JM, Paknikar KM. Nanotoxicology and in vitro studies: the need of the hour. Toxicol Appl Pharmacol 2012;258:151-65. doi: 10.1016/j.taap.2011.11.010

29. Tice RR, Agurell E, Anderson D, Burlinson B, Hartmann A, Kobayashi H, Miyamae Y, Rojas E, Ryu JC, Sasaki YF. Single cell gel/comet assay: guidelines for in vitro and in vivo genetic toxicology testing. Environ Mol Mutagen 2000;35:206-21. doi: 10.1002/(sici)1098-2280(2000)35:3<206::aidem8>3.0.co;2-j

30. Machado Cda S, Venancio VP, Aissa AF, Hernandes LC, de Mello MB, Del Lama JE, Marzocchi-Machado CM, Bianchi ML, Antunes LM. Vitamin D3 deficiency increases DNA damage and the oxidative burst of neutrophils in a hypertensive rat model. Mutat Res Genet Toxicol Environ Mutagen 2016;798-799:19-26. doi: 10.1016/j. mrgentox.2016.01.005

31. Salamone M, Heddle J, Stuart E, Katz M. Towards an improved micronucleus test: studies on 3 model agents, mitomycin C, cyclophosphamide and dimethylbenzanthracene. Mutat Res 1980;74:347-56. doi: 10.1016/01651161(80)90193-4

32. Schmid W. The micronucleus test. Mutat Res 1975;31:9-15. doi: 10.1016/0165-1161(75)90058-8

33. Liu Y, Liu C, Qin X, Zhu M, Yang Z. The change of spatial cognition ability in depression rat model and the possible association with down-regulated protein expression of TRPC6. Behav Brain Res 2015;294:186-93. doi: 10.1016/j. bbr.2015.07.062

34. Sarhan OM, Hussein RM. Effects of intraperitoneally injected silver nanoparticles on histological structures and blood parameters in the albino rat. Int J Nanomedicine 2014;9:150517. doi: $10.2147 /$ IJN.S56729

35. Vinković Vrček I, Žuntar I, Petlevski R, Pavičić I, Dutour Sikirić M, Ćurlin M, Goessler W. Comparison of in vitro toxicity of silver ions and silver nanoparticles on human hepatoma cells. Environ Toxicol 2016;31:679-92. doi: 10.1002/tox.22081

36. Wei L, Lu J, Xu H, Patel A, Chen ZS, Chen G. Silver nanoparticles: synthesis, properties, and therapeutic applications. Drug Discov Today 2015;20:595-601. doi: 10.1016/j.drudis.2014.11.014

37. Wang E, Huang Y, Du Q, Sun Y. Silver nanoparticle induced toxicity to human sperm by increasing ROS(reactive oxygen species) production and DNA damage. Environ Toxicol Pharmacol 2017;52:193-9. doi: 10.1016/j.etap.2017.04.010

38. Naik E, Dixit VM. Mitochondrial reactive oxygen species drive proinflammatory cytokine production. J Exp Med 2011;208:417-20. doi: 10.1084/jem.20110367

39. Scaffidi P, Misteli T, Bianchi ME. Release of chromatin protein HMGB1 by necrotic cells triggers inflammation. Nature 2002;418:191-5. doi: 10.1038/nature00858

40. Dietrich A, Chubanov V, Gudermann T. Renal TRPathies. J Am Soc Nephrol 2010;21:736-44. doi: 10.1681/ ASN.2009090948 
41. Yu S, Yu L. Dexamethasone resisted podocyte injury via stabilizing TRPC6 expression and distribution. Evid Based Complement Alternat Med 2012;2012:652059. doi: $10.1155 / 2012 / 652059$

42. Ray PC, Yu H, Fu PP. Toxicity and environmental risks of nanomaterials: challenges and future needs. J Environ Sci Health C Environ Carcinog Ecotoxicol Rev 2009;27:1-35. doi: $10.1080 / 10590500802708267$

43. Xia T, Kovochich M, Liong M, Madler L, Gilbert B, Shi H, Yeh JI, Zink JI, Nel AE. Comparison of the mechanism of toxicity of zinc oxide and cerium oxide nanoparticles based on dissolution and oxidative stress properties. ACS Nano 2008;2:2121-34. doi: 10.1021/nn800511k
44. Wang S, Lu W, Tovmachenko O, Rai US, Yu H, Ray PC. Challenge in understanding size and shape dependent toxicity of gold nanomaterials in human skin keratinocytes. Chem Phys Lett 2008;463:145-9. doi: 10.1016/j.cplett.2008.08.039

45. Shaligram S, Campbell A. Toxicity of copper salts is dependent on solubility profile and cell type tested. Toxicol In Vitro 2013;27:844-51. doi: 10.1016/j.tiv.2012.12.026

46. Lu W, Senapati D, Wang S, Tovmachenko O, Singh AK, Yu H, Ray PC. Effect of surface coating on the toxicity of silver nanomaterials on human skin keratinocytes. Chem Phys Lett 2010;487:92-6. doi: 10.1016/j.cplett.2010.01.027

\section{Nefrotoksičnost i genotoksičnost srebrnih nanočestica u mladih štakora i mogući mehanizmi njihova djelovanja}

Zbog široke primjene i rizika od štetnog djelovanja srebrnih nanočestica (AgNP) na mladi organizam u razvoju, u središtu pažnje ovog istraživanja bila je njihova nefrotoksičnost i genotoksičnost u 32 mužjaka Wistar štakora od 14. dana starosti koji su intraperitonealno primali otopinu AgNP-a (3 mg/kg tjelesne težine). Štakori su nasumce raspoređeni u tri izložene skupine (osam po skupini) - prva jedan tjedan, druga dva, a treća tri - i jednu kontrolnu skupinu, koja je primala fiziološku otopinu. Kad su štakori navršili osam tjedana, napravili smo pretrage krvi na kreatinin i mokraće na mikro albumin, a zatim i histološku pretragu s bojenjem hematoksilinom i eozinom (H\&E). U životinja koje su tri tjedna bile izložene AgNP-u utvrđena je proteinurija, a H\&E bojenjem utvrđene su patološke promjene na presjecima bubrežnog tkiva. Alkalnim komet testom otkriveno je oštećenje DNA u skupinama izloženima dva odnosno tri tjedna. Svi naši rezultati upućuju na to da kronična izloženost AgNP-u, makar i u niskim dozama, može utjecati na zdravlje životinja. Primarni je razlog za to vjerojatno povišena proizvodnja reaktivnih kisikovih spojeva (engl. reactive oxygen species, krat. ROS), koja je rasla s vremenom izloženosti. Visokoreaktivni kisikovi spojevi mogu uzrokovati velika strukturna oštećenja bjelančevina i DNA, izmijeniti ekspresiju ionskih kanala bjelančevina te potaknuti upalu. Rezultati našega in vivo istraživanja pozivaju ne samo na zabrinutost zbog nefrotoksičnih i genotoksičnih učinaka srebrnih nanočestica na mlade organizme nego i na potrebu daljnjeg istraživanja promjenjivih svojstava nanočestica ne bi li se rizik od njihova štetnog djelovanja sveo na najmanju moguću razinu. 